
\title{
25 Research Soure \\ Echocardiographic Findings and Associated Factors in HIV Infected Patients at a Tertiary Hospital in Ethiopia
}

\section{Esubalew Woldeyes ( $\nabla$ esubalew49@gmail.com )}

St. Paul's Hospital Millennium Medical College

\section{Hailu Abera Mulatu}

St. Paul's Hospital Millennium Medical College

\section{Abiy Ephrem}

St. Paul's Hospital Millennium Medical College

Henok Benti

St. Paul's Hospital Millennium Medical College

\section{Mehari Wale Alem}

St. Paul's Hospital Millennium Medical College

\section{Ahmed Ibrahim Ahmed}

Houston Methodist Debakey Heart and Vascular Center

\section{Henok Fisseha}

St. Paul's Hospital Millennium Medical College

\section{Research Article}

Keywords: Human Immunodeficiency Virus, Echocardiography, cardiovascular diseases

Posted Date: August 26th, 2021

DOI: https://doi.org/10.21203/rs.3.rs-783271/v1

License: () (1) This work is licensed under a Creative Commons Attribution 4.0 International License. Read Full License 


\section{Abstract}

Background: Non-communicable diseases including cardiovascular diseases are becoming an important part of Human Immunodeficiency Virus (HIV) care. Echocardiography is a useful non-invasive tool to assess for cardiac disease and different echocardiographic abnormalities have been seen previously. Available evidence on the echocardiographic abnormalities in Ethiopia is scarce. The aim of this study was to investigate the echocardiographic abnormalities in HIV infected patients and factors associated with the findings.

Methods: A cross-sectional study was conducted on 285 patients with HIV infection including collection of clinical and echocardiographic data. Logistic regression was used to examine the association between echocardiographic abnormalities and associated factors with variables with a $p$-value of $<0.05$ in the multivariate model considered statistically significant.

Results: Diastolic dysfunction was the most common abnormality seen in $30.1 \%$ of the participants followed by regional wall motion abnormality $(22.2 \%)$, left ventricular hypertrophy $(10.3 \%)$, enlarged left atrium (8.1\%), pulmonary hypertension (3.5\%) and pericardial effusion (2.1\%). Almost all patients had normal left ventricle systolic function. Diastolic dysfunction was independently associated with increasing age, elevated blood pressure and left ventricular hypertrophy while regional wall motion abnormality was associated with male gender, increasing age and abnormal fasting blood glucose. Left ventricular hypertrophy was associated with increasing age and blood pressure and the later was associated with left atrial enlargement. The level of immunosuppression did not affect echocardiography findings.

Conclusions: A high prevalence of echocardiographic abnormalities was found and included diastolic dysfunction, regional wall motion abnormality, left ventricular hypertrophy and left atrial enlargement. Male gender, age above 50 years, elevated blood pressure and elevated fasting blood glucose were associated with echocardiographic abnormalities. Appropriate screening and treatment of echocardiographic abnormalities is needed.

\section{Background}

Human Immunodeficiency Virus (HIV) infection, with the widespread use of Antiretroviral Treatment (ART), is showing an evolving trend from a predominantly infectious ailment to a systemic disease that leads to increased manifestations of non-communicable diseases (1). With increased longevity, patients are faced with increasing morbidity and mortality from cardiovascular diseases $(2,3)$. HIV infected patients have increased risk of developing cardiac dysfunction and a large share of the suffering is considered to be related to HIV infection itself (4).

During earlier periods of the infection, the most common cardiovascular manifestations of HIV were pericardial effusion and cardiomyopathy (5). This pattern has persisted to be seen in developing countries but in affluent societies, with widespread use of ART, it is shifting gradually to diastolic dysfunction, 
coronary artery disease and pulmonary hypertension (5). Echocardiography is a useful non-invasive diagnostic imaging modality that is valuable in the diagnosis of these cardiac manifestations (6).

Different mechanisms have been proposed for development of cardiac disease in HIV. Direct infection of myocardium by the virus, opportunistic infections, chronic inflammation, lipodystrophy and cardiac autoimmunity are included among others $(4,7,8)$. Certain ART medications, use of substances such as alcohol and nutritional deficiency also contribute $(7,8)$.

Knowing the adverse effects of the infection on the heart early by readily available and non-invasive diagnostic test can help patients prevent morbidity and can be accomplished by the use of echocardiography for screening and monitoring in this group of population (9).

Much of the evidence regarding this subject is mostly derived from studies outside of Africa. In addition, data regarding the echocardiographic abnormalities in HIV infected patients in Ethiopia is very scanty and has mostly focused on specific diagnosis and not on comprehensive echocardiographic assessment. In this study we investigate the echocardiographic findings in HIV infected patients and factors associated with the findings.

\section{Methods}

\section{Study design and participants}

A cross sectional study was conducted on patients with HIV infection on ART at St. Paul's hospital millennium medical college (SPHMMC) HIV treatment clinic in Addis Ababa, Ethiopia. Adult HIV clinic at SPHMMC has a total of 4,685 patients on active follow-up, with average monthly patient of 1,700 and serves up to 70 patients per day. All patients are on ART unless deferred for clinical reasons. There are 2,552 patients that are expected to visit the clinic over the data collection period of 6 weeks from January 6, 2019 to February 15, 2019. Assuming a 26\% prevalence of echocardiographic abnormalities in HIV infected patients (10), $5 \%$ margin of error, $95 \%$ confidence interval and adjusting for the finite size of the population using population correction formula, the calculated sample size was 265 patients and 285 patients were finally included in the study. Selection of participants was done using systematic random sampling from routine ART clinic visit, with every ninth patient coming in the morning for follow up invited to participate in the study and the subsequent patient included if the ninth patient did not give consent to participate. All patients above 18 years of age that gave written consent to participate were included and pregnant patients were excluded from the study.

\section{Data collection}

A questionnaire was conducted regarding participants' socio-demographic characteristics and cardiovascular risk factors. Data regarding HIV infection was retrieved from patient follow-up charts. Subsequently, physical examination including blood pressure measurement, weight and height measurement was done. The diagnosis of Hypertension was made in accordance with $2018 \mathrm{ESC} / \mathrm{ESH}$ (European society of cardiology and European society of hypertension) guideline for management of 
arterial hypertension and hypertension was diagnosed if systolic blood pressure was $140 \mathrm{~mm} / \mathrm{Hg}$ and/or diastolic blood pressure was $90 \mathrm{~mm} / \mathrm{Hg}$ and above (11). Body mass index (BMI) was classified according to World Health Organization classification (12). Biochemical analysis was done to determine participants' fasting blood glucose (FBG) and serum cholesterol levels.

Finally, two-dimensional transthoracic echocardiography, including $\mathrm{M}$ mode, color Doppler, pulse wave, and continuous wave Doppler was done by experienced cardiologists using an GE VIVID E9 with 1-5 MHz transducers. Participants were placed in the left lateral supine position and examined in standard parasternal and apical views. Echo and Doppler study measurements and interpretation was made in accordance with recommendations of the American Society of Echocardiography guidelines.

Normal chamber measurement values were defined according to current guidelines, along with measurement of ejection fraction (EF) by quantitative biplane Simpson method. Global left ventricle (LV) systolic function was estimated using ejection fraction which was considered normal if it was $52-72 \%$ and $54-74 \%$, and reduced if it was less than or equal to $52 \%$ and $53 \%$ in males and females respectively (13). Diastolic function was categorized according to the progression of diastolic dysfunction as follows: normal; Grade I, defined as impaired relaxation without evidence of increased filling pressures; Grade II, defined as impaired relaxation associated with moderate elevation of filling pressures or pseudo normal filling, and Grade III, defined as advanced reduction in compliance or reversible or fixed restrictive filling (14). LV size was estimated based on the internal diastolic diameter in $\mathrm{M}$ mode and normal values were considered as $42-58.4 \mathrm{~mm}$ and $37.8-52.2 \mathrm{~mm}$ for males and females respectively and right ventricle (RV) basal diameter was considered normal if $25-41 \mathrm{~mm}$. Left atrium anteroposterior dimension was considered normal if 30-40 mm and $27-38 \mathrm{~mm}$ in males and females respectively (13). Right atrium minor axis dimension was considered normal if 29 to $45 \mathrm{~mm}$ (15).

Pulmonary hypertension was defined by a tricuspid regurgitant velocity of $\geq 2.9 \mathrm{~m} / \mathrm{sec}$ on transthoracic echocardiography which translated to a right ventricular pressure above $35 \mathrm{mmHg}$. A tricuspid regurgitant velocity $3.5 \mathrm{~m} / \mathrm{sec}$, which translates into a pulmonary arterial pressure/right ventricular systolic pressure of $\geq 50 \mathrm{mmHg}$, was considered moderate-to-severe pulmonary hypertension (16). LV septal wall thickness was considered normal if it was $\leq 10 \mathrm{~mm}$ in males and $9 \mathrm{~mm}$ in females. Furthermore, mild left ventricular hypertrophy (LVH) (10 - $12 \mathrm{~mm}$, for women and 11-13 mm for men), moderate LVH (L 13-15 mm for women and 14-16 $\mathrm{mm}$ for men) and severe LVH (>15 $\mathrm{mm}$ for women and $>16 \mathrm{~mm}$ for men) classifications were used (13). Pericardial effusion was considered small when less than $10 \mathrm{~mm}$, moderate when 10-20 mm, large when $>20 \mathrm{~mm}$, and very large if $>25 \mathrm{~mm}$ (17).

If any abnormality was detected, patients were linked to a cardiologist for follow up.

\section{Data analysis}

Data was summarized using percentages, mean, standard deviation (SD) and presented in tables and text. The independent Student t-test was used to compare continuous variables and the Chi square and Fisher's exact test, when assumptions of chi-square test were not met were used to compare categorical variables. 
Logistic regression was used to examine the association between echocardiographic abnormalities and associated factors. Variables with P-value $<0.2$ in the univariate analysis were included in the multivariate logistic regression model. All variables with a $\mathrm{p}$-value of $<0.05$ in the multivariate model were considered statistically significant. Associations between variables were presented in odds ratios (OR) with $95 \%$ confidence interval $(\mathrm{Cl})$.

\section{Ethical approval}

This study was approved by the Institutional Review Board of SPHMMC. Written informed consent was obtained from all participants. Each participant's information was collected using anonymous questionnaire.

\section{Results}

\section{Sociodemographic characteristics}

A total of 285 HIV infected patients on ART participated in the study, out which 90 (31.6\%) were male and $195(68.4 \%)$ were female. The mean age (SD) of study participants was 44.7 years (10.3), with the youngest participant being 19 and the oldest 83 years old. Female participants were younger with $38.9 \%$ being less than 40 years compared to $14.6 \%$ of males $(P<0.001)$.

The mean of the most recent Cluster of differentiation 4 (CD4) count (SD) was $566.9 \mathrm{cell} / \mathrm{s} / \mathrm{mm}^{3}$ (269) and ranged from $55-1477$ cells $/ \mathrm{mm}^{3}$. Viral load was done in $74 \%$ of the participants and the mean of the most recent result was 5,634 copies $/ \mathrm{mL}$ (undetectable $-272,719 \mathrm{copies} / \mathrm{mL}$ ) with $73.5 \%$ having undetectable viral load. The mean number of years since HIV diagnosis was 10.6 (3.9) years. The mean duration on ART was 10.07 (3.9) years with males being on ART for longer mean years than females $(P=0.016)$. Around 70.7\% were taking Tenofovir Disoproxil Fumarate (TDF) and Lamivudine with Efavirenz or Nevirapine.

Only $5(1.8 \%)$ were active smokers and $7(2.5 \%)$ consumed alcohol in the past one month.

Measurement of fasting blood glucose was done and $66.1 \%$ had normal measurements. Out of the total participants, $21.6 \%$ had hypertension based on the mean blood pressure measurement. Dyslipidemia was seen in $67.6 \%$ and $10.9 \%$ were obese (Table 1 ). 
Table 1

Sociodemographic and clinical characteristics of participants, SPHMMC, Addis Ababa, 2020

\begin{tabular}{|c|c|c|c|c|}
\hline & Total & Male N (\%) & Female N (\%) & P-value \\
\hline Age group & & & & $<0.001$ \\
\hline$\leq 39$ years & $85(31 \%)$ & $13(14.6 \%)$ & $72(38.9 \%)$ & \\
\hline $40-59$ years & $163(59.5 \%)$ & $67(75.3 \%)$ & $96(51.9 \%)$ & \\
\hline$\geq 60$ & $26(9.5 \%)$ & $9(10.1 \%)$ & $17(9.2 \%)$ & \\
\hline CD4 count & & & & 0.614 \\
\hline$<200$ & $17(7.2 \%)$ & $6(8.1 \%)$ & $11(6.7 \%)$ & \\
\hline $200-349$ & $35(14.8 \%)$ & $8(10.8 \%)$ & $27(16.6 \%)$ & \\
\hline $350-499$ & $50(21.1 \%)$ & $18(24.3 \%)$ & $32(19.6 \%)$ & \\
\hline$\geq 500$ & $135(57 \%)$ & $42(56.8 \%)$ & $93(57.1 \%)$ & \\
\hline Viral load & & & & 0.337 \\
\hline$<50$ & $166(79 \%)$ & $54(83.1 \%)$ & $112(77.2 \%)$ & \\
\hline$\geq 50$ & $44(21 \%)$ & $11(16.9 \%)$ & $33(22.8 \%)$ & \\
\hline Current regimen & & & & 0.31 \\
\hline TDF/3TC/EFV OR NVP & 199 (70.8\%) & $61(69.3 \%)$ & $138(71.5 \%)$ & \\
\hline AZT/3TC/EFV OR NVP & $56(19.9 \%)$ & $17(19.3 \%)$ & $39(20.2 \%)$ & \\
\hline TDF/3TC/LPV/R & $4(1.4 \%)$ & $3(3.4 \%)$ & $1(0.5 \%)$ & \\
\hline Other & $22(7.8 \%)$ & $7(8 \%)$ & $15(7.8 \%)$ & \\
\hline Blood pressure & & & & 0.008 \\
\hline $\mathrm{SBP}<130$ and $\mathrm{DBP}<85$ & $183(65.4 \%)$ & $46(52.3 \%)$ & $137(71.4 \%)$ & \\
\hline SBP $130-139$ and/or DBP 85-89 & $36(12.9 \%)$ & $13(14.8 \%)$ & $23(12 \%)$ & \\
\hline SBP $140-159$ and/or DBP 90-99 & $41(14.6 \%)$ & $21(23.9 \%)$ & $20(10.4 \%)$ & \\
\hline $\mathrm{SBP} \geq 160$ and/or $\mathrm{DBP} \geq 100$ & $20(7.1 \%)$ & $8(9.1 \%)$ & $12(6.3 \%)$ & \\
\hline Current tobacco smoker & $5(1.8 \%)$ & $3(3.4 \%)$ & $2(1 \%)$ & 0.181 \\
\hline Alcohol drink in the last 1 month & $7(2.5 \%)$ & $3(3.4 \%)$ & $4(2.1 \%)$ & 0.682 \\
\hline Fasting blood glucose & & & & 0.905 \\
\hline
\end{tabular}

3TC - Lamivudine, ART - Anti-Retroviral Treatment, AZT - Zidovudine, EFV - Efavirenz, LPV Lopinavir/ritonavir, NVP - Nevirapine, TDF - Tenofovir Disoproxil Fumarate 


\begin{tabular}{|lllll|}
\hline & Total & Male N (\%) & Female N (\%) & P-value \\
\hline Less than 100 & $180(66.2 \%)$ & $54(64.3 \%)$ & $126(67 \%)$ & \\
\hline $100-125$ & $67(24.6 \%)$ & $22(25.2 \%)$ & $45(23.9 \%)$ & \\
\hline 126 or more & $25(9.2 \%)$ & $8(9.5 \%)$ & $17(9 \%)$ & \\
\hline Dyslipidemia & $188(67.6 \%)$ & $63(71.6 \%)$ & $125(65.8 \%)$ & 0.336 \\
\hline Obesity & $30(10.9 \%)$ & $10(11.5 \%)$ & $20(10.6 \%)$ & 0.821 \\
\hline Mean years since diagnosis & $10.6 \pm 3.9$ & $11.2 \pm 4.1$ & $10.3 \pm 3.9$ & 0.071 \\
\hline Mean years on ART & $10.07 \pm 3.9$ & $10.9 \pm 3.9$ & $9.7 \pm 3.9$ & 0.016 \\
\hline $\begin{array}{l}\text { 3TC - Lamivudine, ART - Anti-Retroviral Treatment, AZT - Zidovudine, EFV - Efavirenz, LPV - } \\
\text { Lopinavir/ritonavir, NVP - Nevirapine, TDF - Tenofovir Disoproxil Fumarate }\end{array}$ & & \\
\hline
\end{tabular}

\section{Echocardiography parameters}

All but one patient had normal ejection fraction with median ejection fraction of $66 \%$ (Interquartile range $62-70 \%)$. Most participants (69.9\%) had normal diastolic function. More males (59.4\%) had diastolic dysfunction compared to females $(23 \%)(P<0.01)$. Diastolic dysfunction was seen more often in participants above 60 years of age (40.3\%) compared to individuals below 40 years of age $(9.2 \%)(P<$ $0.001)$. It was also more frequently seen in hypertensive individuals $(P<0.001)$, obese participants $(P=$ $0.0012)$ and in individuals who have been on ART for more than 10 years $(P=0.032)$.

Most of the participants had normal chamber dimensions. The left atrium was enlarged in $23(8.3 \%)$ of the participants while right ventricle, left ventricle and right atrium was enlarged in $1.1 \%, 0.4 \%$ and $1.1 \%$ of participants respectively. Left atrial enlargement was more likely to be seen in hypertensive individuals $(21.3 \%$ Vs $4.5 \%)(P<0.001)$. It was also seen more frequently in obese participants $(23.3 \%$ Vs $6.1 \%)(P=$ $0.001)$ and with increasing duration of HIV diagnosis $(P=0.007)$

Ten patients (3.5\%) had elevated systolic pulmonary artery pressure.

Among the participants $8.5 \%$ had mild left ventricular hypertrophy and $1.8 \%$ had moderate to severe hypertrophy. LVH was seen more commonly in males $(16.5 \% \mathrm{Vs} 7.7 \%)(P=0.013)$ and in participants 40 years of age and above $(14.6 \% \mathrm{Vs} 1.1 \%)(P=0.002)$. As expected, $\mathrm{LVH}$ was seen more often in individuals with mean blood pressure in the hypertensive range $(26.2 \%)$ compared to normotensive ones $(6 \%)(P<$ 0.001) (Table 2).

One patient had thrombus in the left ventricle and 8 patients had congenital heart disease. Among the valve lesions, two participants had moderate or severe mitral regurgitation and one had moderate or severe aortic regurgitation. Three participants had moderate or severe aortic stenosis and one patient had 
moderate or severe mitral stenosis. Six patients had pericardial effusion. Two participants had vegetation one on the mitral and the other on the aortic valve. No patient had atrial thrombus. 
Table 2

Echocardiography parameters of patients, SPHMMC, Addis Ababa, 2020

\begin{tabular}{|c|c|c|c|c|}
\hline Echocardiography parameter & Total & $\begin{array}{l}\text { Male N } \\
(\%)\end{array}$ & $\begin{array}{l}\text { Female N } \\
(\%)\end{array}$ & $\begin{array}{l}\mathrm{P}- \\
\text { value }\end{array}$ \\
\hline Ejection fraction & $66 \pm 5.6$ & & & \\
\hline Reduced ejection fraction & $1(0.4 \%)$ & 0 & $1(0.5 \%)$ & 0.453 \\
\hline Mean left ventricle end-diastolic diameter & $42.1 \pm 5.1$ & & & \\
\hline Enlarged left ventricle end-diastolic diameter & $1(0.4 \%)$ & 0 & $1(0.5 \%)$ & 0.494 \\
\hline Mean left atrium end-diastolic diameter & $33.1 \pm 4.6$ & & & \\
\hline Enlarged left atrium end-diastolic diameter & $23(8.1 \%)$ & $\begin{array}{l}11(12.4 \\
\%)\end{array}$ & $12(6.2 \%)$ & 0.078 \\
\hline Mean right ventricle end-diastolic diameter & $31.7 \pm 4.5$ & & & \\
\hline Enlarged right ventricle end-diastolic diameter & $3(1.1 \%)$ & $2(2.2 \%)$ & $1(0.5 \%)$ & 0.192 \\
\hline $\begin{array}{l}\text { Mean right atrium end-diastolic minor axis } \\
\text { dimension }\end{array}$ & $33.6 \pm 4.4$ & & & \\
\hline $\begin{array}{l}\text { Enlarged right atrium end-diastolic minor axis } \\
\text { dimension }\end{array}$ & $1(0.4 \%)$ & $1(1.1 \%)$ & 0 & 0.319 \\
\hline \multicolumn{5}{|l|}{ Left ventricle diastolic dysfunction } \\
\hline None & $\begin{array}{l}197 \\
(69.9 \%)\end{array}$ & $\begin{array}{l}48(69.6 \\
\%)\end{array}$ & $147(77 \%)$ & $<0.001$ \\
\hline Grade 1 & $\begin{array}{l}75 \\
(26.6 \%)\end{array}$ & $\begin{array}{l}38(55.1 \\
\%)\end{array}$ & $37(19.3 \%)$ & \\
\hline Grade 2 & $10(3.5 \%)$ & $3(4.3 \%)$ & $7(3.7 \%)$ & \\
\hline Systolic pulmonary artery pressure & & & & 0.838 \\
\hline Normal & $\begin{array}{l}273 \\
(96.5 \%)\end{array}$ & $\begin{array}{l}86(97.7 \\
\%)\end{array}$ & $185(\%)$ & \\
\hline Mild elevation & $5(1.8 \%)$ & $1(1.1 \%)$ & $4(\%)$ & \\
\hline Moderate elevation & $1(0.4 \%)$ & 0 & $1(\%)$ & \\
\hline Severe elevation & $4(1.4 \%)$ & $1(1.1 \%)$ & $3(\%)$ & \\
\hline Pericardial effusion & $6(2.1 \%)$ & $1(1.1 \%)$ & $5(2.6 \%)$ & 0.669 \\
\hline Left ventricular hypertrophy & & & & 0.013 \\
\hline None & $\begin{array}{l}252 \\
(89.7 \%)\end{array}$ & $\begin{array}{l}71(83.5 \\
\%)\end{array}$ & $\begin{array}{l}179(92.3 \\
\%)\end{array}$ & \\
\hline Mild & $24(8.5 \%)$ & $\begin{array}{l}12(14.1 \\
\%)\end{array}$ & $12(6.2 \%)$ & \\
\hline
\end{tabular}




\begin{tabular}{|lllll|}
\hline Echocardiography parameter & Total & $\begin{array}{l}\text { Male N } \\
(\%)\end{array}$ & $\begin{array}{l}\text { Female N } \\
(\%)\end{array}$ & $\begin{array}{l}\mathbf{P}- \\
\text { value }\end{array}$ \\
\hline Moderate & $2(0.7 \%)$ & $2(2.4 \%)$ & 0 \\
\hline Severe & $3(1.1 \%)$ & 0 & $3(1.5 \%)$ & \\
\hline
\end{tabular}

Most of the participants (71.4\%) had a final conclusion of a normal echocardiography study. The most common abnormal finding was regional wall motion abnormality seen in $22.2 \%$ of the participants followed by congenital heart disease in $3.2 \%$ and rheumatic valvular heart disease in $1.2 \%$. Females were more likely to have a normal echocardiography study (79.4\%) compared to males (53.8\%) and males were more likely to have regional wall motion abnormality $(35.9 \%)$ compared to females $(15.9 \%)(P=$ 0.001). Regional wall motion abnormality was diagnosed more frequently in individuals above 60 years of age with as high as $34.8 \%$ having such finding compared to $6.2 \%$ of individuals below 40 years of age $(\mathrm{P}<$ 0.001). It was also more commonly seen in hypertensive participants $(P$-Value $=0.027)$, participants with dyslipidemia $(P=0.021)$ and with those with longer years on ART for more than 10 years $(P=0.007)$ (Table 3).

Table 3

Echocardiography conclusion of patients, SPHMMC, Addis Ababa, 2020

\begin{tabular}{|lllll|}
\hline Conclusion of echocardiography & Total & Male N (\%) & Female N (\%) & $\mathbf{P = 0 . 0 0 1}$ \\
\hline Normal & $177(71.4 \%)$ & $42(53.8 \%)$ & $135(79.4 \%)$ \\
\hline Regional wall motion abnormality & $55(22.2 \%)$ & $28(35.9 \%)$ & $27(15.9 \%)$ \\
\hline Rheumatic Valvular & $3(1.2 \%)$ & $2(2.6 \%)$ & $1(0.6 \%)$ \\
\hline Non-Rheumatic Valvular & $2(.8 \%)$ & $2(2.6 \%)$ & $2(1.2 \%)$ \\
\hline Cardiomyopathy & $2(0.8 \%)$ & $1(1.3 \%)$ & $1(0.6 \%)$ \\
\hline Hypertensive heart disease & $1(0.4 \%)$ & $2(2.6 \%)$ & $1(0.6 \%)$ \\
\hline Congenital & $8(3.2 \%)$ & $5(6.4 \%)$ & $3(1.8 \%)$ \\
\hline
\end{tabular}

\section{Predictors of echocardiography parameters}

In multivariable analysis, participants with elevated blood pressure were 4 times as likely to have LVH on echocardiography $(95 \% \mathrm{Cl} 1.657-9.585 ; \mathrm{P}=0.002)$ and participants above 50 years of age had 3 times increased risk of having LVH $(95 \% \mathrm{Cl} 1.213-7.095 ; \mathrm{P}=0.017)$. Hypertension also increased the odds of having an enlarged left atrium by 4.1 times $(95 \% \mathrm{Cl} 1.3-13.15 ; \mathrm{P}=0.0016)$ and the odds of having diastolic dysfunction by 2.3 times (95\% Cl 1.05-4.93). LVH (AOR 12.914, 95\% Cl 3.36-49.61; P<0.001) and age above 50 (AOR $3.4,95 \% \mathrm{Cl} 1.717-6.725 ; \mathrm{P}<0.001$ ) were other factors independently associated 
with diastolic dysfunction. Ischemic heart disease was more likely to be seen in males (AOR 2.54, 95\% Cl 1.197-5.37; $P=0.015$ ), in participants above 50 years of age (AOR 3.552, 95\% $\mathrm{Cl} 1.631-7.733 ; \mathrm{P}=0.001$ ) and participants with FBG above $100 \mathrm{mg} / \mathrm{dL}$ (AOR 2.297, 95\% Cl 1.1-4.8; $\mathrm{P}=0.027$ ). There were no factors independently associated with elevated systolic pulmonary artery pressure. The severity of HIV infection did not contribute significantly to echocardiography findings (Table 4). 
Table 4

Multivariate logistic regression of factors associated with echocardiography parameters, SPHMMC, Addis Ababa, 2020

\begin{tabular}{|c|c|c|c|c|c|c|c|c|c|c|}
\hline & \multicolumn{2}{|l|}{ LVH } & \multicolumn{2}{|c|}{$\begin{array}{l}\text { Enlarged left } \\
\text { atrium }\end{array}$} & \multicolumn{2}{|c|}{$\begin{array}{l}\text { Diastolic } \\
\text { dysfunction }\end{array}$} & \multicolumn{2}{|c|}{$\begin{array}{l}\text { Ischemic heart } \\
\text { disease }\end{array}$} & \multicolumn{2}{|c|}{$\begin{array}{l}\text { Elevated } \\
\text { PASP }\end{array}$} \\
\hline & $\begin{array}{l}\mathrm{AOR} \\
95 \% \\
\mathrm{Cl}\end{array}$ & $\begin{array}{l}\text { P- } \\
\text { value }\end{array}$ & $\begin{array}{l}\text { AOR } \\
95 \% \\
\mathrm{Cl}\end{array}$ & $\begin{array}{l}\text { P- } \\
\text { value }\end{array}$ & $\begin{array}{l}\text { AOR } \\
95 \% \\
\mathrm{Cl}\end{array}$ & $\begin{array}{l}\mathrm{P}- \\
\text { value }\end{array}$ & $\begin{array}{l}\text { AOR } \\
95 \% \\
\mathrm{Cl}\end{array}$ & $\begin{array}{l}\text { P- } \\
\text { value }\end{array}$ & $\begin{array}{l}\text { AOR } \\
95 \% \\
\mathrm{Cl}\end{array}$ & $\begin{array}{l}\text { P- } \\
\text { value }\end{array}$ \\
\hline \multicolumn{11}{|l|}{ Gender } \\
\hline Female & & & & & & & 1 & & & \\
\hline Male & & & & & & & $\begin{array}{l}2.54 \\
(1.2- \\
5.37)\end{array}$ & 0.015 & & \\
\hline \multicolumn{11}{|l|}{ Age } \\
\hline$\leq 50$ & 1 & & & & 1 & & 1 & & & \\
\hline $\begin{array}{l}\text { Above } \\
50\end{array}$ & $\begin{array}{l}2.93 \\
(1.21- \\
7.1)\end{array}$ & 0.017 & & & $\begin{array}{l}3.4 \\
(1.72- \\
6.73)\end{array}$ & 0.00 & $\begin{array}{l}3.55 \\
(1.63- \\
7.73)\end{array}$ & 0.001 & & \\
\hline \multicolumn{11}{|l|}{$\begin{array}{l}\text { Blood } \\
\text { pressure }\end{array}$} \\
\hline Normal & 1 & & 1 & & 1 & & & & & \\
\hline Elevated & $\begin{array}{l}4.4 \\
(1.82- \\
10.63)\end{array}$ & 0.001 & $\begin{array}{l}4.14 \\
(1.3- \\
13.15)\end{array}$ & 0.0016 & $\begin{array}{l}2.27 \\
(1.05- \\
4.93)\end{array}$ & 0.038 & & & & \\
\hline \multicolumn{11}{|l|}{$\begin{array}{l}\text { Fasting } \\
\text { blood } \\
\text { glucose }\end{array}$} \\
\hline $\begin{array}{l}<100 \\
\mathrm{mg} / \mathrm{dL}\end{array}$ & & & & & & & 1 & & & \\
\hline $\begin{array}{l}\geq 100 \\
\mathrm{mg} / \mathrm{dL}\end{array}$ & & & & & & & $\begin{array}{l}2.297 \\
(1.1- \\
4.8)\end{array}$ & 0.027 & & \\
\hline \multicolumn{11}{|l|}{ LVH } \\
\hline No & & & & & 1 & & & & & \\
\hline Yes & & & & & $\begin{array}{l}12.91 \\
(3.36- \\
49.61)\end{array}$ & 0.00 & & & & \\
\hline
\end{tabular}




\section{Discussion}

There was a high prevalence of echocardiographic abnormalities found in this study of HIV infected individuals. The prevailing abnormalities identified were diastolic dysfunction, regional wall motion abnormality, LVH and left atrial dilation.

Diastolic dysfunction (DD), predominantly grade I (impaired relaxation) was reported in $30.1 \%$ of the participants with normal systolic function. Similar to our finding, diastolic dysfunction has been reported to be the most common finding previously $(7,9,18,19)$. High prevalence ranging from $42.8 \%$ in India to as high as in $85.7 \%$ in Congo have been reported in the past $(3,7,9,18,19)$. The lowest report of diastolic dysfunction was from a study on patients with early HIV infection of only $2 \%(20)$. Other studies report prevalence from $9.25 \%$ to $19.9 \%(2,21)$ with a recent systematic review reporting pooled prevalence of $29.3 \%$, a number similar to our study (4). Similar to this study, increasing age has been shown to be an independent risk factor for DD in HIV patients (9) and is also a known risk factor in the general population (22). Hypertension and LVH are other risks for DD seen in previous studies also supported by our findings $(3,5,9,22,23)$. HIV infection is also a risk factor for DD by itself (3). The level of immunosuppression and viral load did not affect finding of DD in this or some other studies $(3,7)$. The mechanisms behind DD in HIV infection is multifactorial with hypertension, LVH, direct myocardial viral infection (HIV itself, Mycobacterium avium, Cryptococcus neoformans, Toxoplasma gondii), neoplastic involvement (Lymphoma, Kaposi Sacroma), infiltrative diseases (amyloidosis, tuberculosis), increased inflammation, immunosuppression, increased HIV related atherosclerosis, Nucleoside/Nucleotide reverse transcriptase inhibitor (NRTI) induced mitochondrial damage and cardiomyopathy all potentially contributing $(3,18)$. DD precedes systolic dysfunction and is considered an early finding of myocardial disease that needs follow up (19).

LVH was seen in $10.3 \%$ of our study participants. Previous studies have reported prevalence of LVH from $4 \%$ to $46.9 \%(2,3,18,23-25)$. This variation could be explained by the use of different methods for assessment of LVH including indexing for body surface area and height which was not done in our study. A study done on patients receiving ART showed hypertension to be a risk for LVH, supporting a similar finding in our study (23). Age and hypertension are known risk factors for LVH in the general population (26). The severity of HIV infection was not shown to be a risk for LVH which was also the case from previous findings $(3,23-25)$. A study that compared HIV infected patients to controls have shown that the infection itself increases risk of LVH (3). Several factors contribute to LVH in HIV. Infection of myocardium and subsequent local release of cytokines, opportunistic infections, use of ART particularly protease inhibitors, subclinical atherosclerosis and state of increased inflammation may all play a role $(3,24)$. LVH is an important precursor to the development of hypertensive heart disease and is associated with cardiovascular mortality and therefore needs close follow-up and treatment $(9,26)$.

Diagnosis of ischemic heart disease was made after the echocardiographic finding of pathologic contraction (regional wall motion abnormality) was seen in $22.2 \%$. This is higher than most previous studies which reported regional wall motion abnormality from $1 \%$ to $23.2 \%(7,9,10,21,27)$. This large difference could be explained by the exclusion of patients with known ischemic heart disease except in 
two of the studies which had the higher prevalence of $13.5 \%$ and $23.2 \%$ which is close to our finding ( 9 , 10). In addition to HIV infection itself, traditional cardiovascular risk factors such as increasing age, male gender and diabetes are supplementary risk factors $(28,29)$. HIV infected patients have increased risk for coronary artery disease with increasing reports $(7,8)$. The major proposed mechanism is increased endothelial dysfunction but also includes lipodystrophy and impaired glucose metabolism $(7,8)$. Certain ART medications increase level of dyslipidemia, insulin resistance and C-reactive protein that increase the risk of coronary artery disease $(5,8)$. They also have increased prevalence of traditional cardiovascular risk factors (5). With increasing longevity and decreasing opportunistic infections, coronary artery disease is expected to become an increasing burden (8). Regional wall motion abnormality is an earlier stage of global LV dysfunction that mandates appropriate management (7).

Left atrial enlargement (LAE) was seen in $8.1 \%$ of our participants. Previous studies reported atrial enlargement from $2.4 \%, 7.7 \%$ and $40 \%(2,9,23)$. The difference could be explained by the use of different cutoff points; usage of linear measurement of LA anteroposterior size and not LA volume measurement in our study; and lack of adjustment made for body surface area. Measurement of linear dimension as opposed to volume does not reflect accurate LA size as the LA enlarges in different dimensions during LA remodeling (13). A study comparing HIV infected and non-infected controls showed larger LA size in infected individuals (3). Hypertension was the only factor independently associated with LAE in our study. Previous studies also found associations with hypertension and $\operatorname{LVH}(2,23)$. Similar to our finding, CD 4 and viral load have not found to be significant previously (23). LAE in the general population, has been shown to be a risk factor for cardiovascular disease including heart failure, atrial fibrillation and stroke (23, 30).

Pericardial effusion was seen in only $6(2.1 \%)$ of the participants which was mostly small or moderate and none of the patients had cardiac tamponade that needed drainage. There is a trend toward decreasing pericardial effusion in HIV patients particularly in developed countries (5). Studies from Congo and Cameroon showed prevalence of effusion of $20.4 \%$ and $46.5 \%$ respectively, showing very high prevalence in Africa $(31,32)$. Others reported prevalence of as low as $4 \%$ to $16.6 \%(7,8,10,21,27,30,33,34)$ and in one study only two patients had pericardial effusion (35). There is a difference of the participants of the studies with some including patients with profound immunosuppression. Pericardial effusion is seen mainly in patients with lower CD4 counts $(10,21,27,33)$. The pathophysiology includes pericarditis caused by the virus and opportunistic infections such as Mycobacterium Tuberculosis, Cryptococcus Neoformans and Herpes Simplex (30). Malignancies such as Lymphoma and Kaposi Sarcoma which have become less common with the widespread use of ART are other potential causes $(5,30)$. Patients with pericardial effusion potentially have higher mortality and therefore needs management as many of the causes are potentially treatable (31).

Reduced ejection fraction was seen in only one patient. A systematic review and meta-analysis published in 2018 showed the pooled prevalence of reduced ejection fraction below $50 \%$ was $12.3 \%$ which was more reduced in patients with AIDS showing the possible relation with immunodeficiency and opportunistic infections and showed lower prevalence in patients on ART potentially explaining the preserved ejection 
fraction in our patients (4). There are some studies where four percent or less of the studied population had low ejection fraction $(2,3,20)$.

Similarly, the systematic review and meta-analysis reported prevalence of pulmonary hypertension in $11.5 \%$ of patients while this study revealed prevalence of $3.6 \%$ (4). A study done in similar Ethiopian setting showed prevalence of $14 \%$ (16). However, other studies also revealed low prevalence of $2.6 \%$ and $3.3 \%(2,7)$. The sensitivity of echocardiography for pulmonary hypertension is not satisfactory and invasive tests may be required in patients with strong clinical suspicion as it is associated with increased mortality $(16,36)$.

There are certain limitations to this study. The cross-sectional nature of the study hinders from making final conclusions about echocardiographic findings and associated factors. There was also no control group for comparison. Despite these limitations our study provides a detailed assessment of echocardiographic findings in a large sample of HIV infected patients and provides new information for the population in the country that was limited to only few echocardiographic parameters. We recommend for future studies to be done taking our limitations into consideration and using a longitudinal study nature that takes the effect of time and long ART use into account.

\section{Conclusions}

In conclusion, a high prevalence of echocardiographic abnormalities was found in this study of HIV infected individuals including diastolic dysfunction, regional wall motion abnormality, LVH and left atrial enlargement. Male gender, age above 50 years, elevated blood pressure and elevated fasting blood glucose were associated with echocardiographic abnormalities. With increasing cardiovascular disease in HIV infected population, appropriate screening, therapeutic interventions and follow-up is needed.

\section{Abbreviations}

3TC - Lamivudine

AOR - Adjusted odds ratio

ART - Antiretroviral Treatment

AZT - Zidovudine

BMI - Body mass index

CD4 - Cluster of differentiation 4

$\mathrm{Cl}$ - Confidence interval

DD - Diastolic dysfunction 
EF - Ejection fraction

EFV - Efavirenz

FBG - Fasting blood glucose

HIV - Human Immunodeficiency Virus

LAE - Left atrial enlargement

LPV - Lopinavir/ritonavir

LV - Left ventricle

LVH - Left ventricular hypertrophy

NVP - Nevirapine

PASP - Pulmonary artery systolic pressure

RV - Right ventricle

OR - Odds ratio

SD - Standard deviation

SPHMMC - St. Paul's hospital millennium medical college

TDF - Tenofovir Disoproxil Fumarate

\section{Declarations}

\section{Ethics approval and consent to participate}

This study was approved by the Institutional Review Board of SPHMMC. Written informed consent was obtained from all participants.

Consent for publication

Written informed consent including for data publication was obtained from all participants.

\section{Availability of data and materials}

The datasets used in this study are available from the corresponding author on reasonable request.

\section{Competing interests}

All authors declare that we have no conflict of interest regarding this manuscript. 


\section{Funding}

The funding was provided by St. Paul's Hospital Millennium Medical College addis Ababa Ethiopia

\section{Authors' contributions}

EW conceived and designed the study; EW, $\mathrm{HM}, \mathrm{AE}, \mathrm{HB}, \mathrm{MA}, \mathrm{AA}$ were involved in data collection; $\mathrm{EW}, \mathrm{HF}$, MA, AA assured the data completeness and data entry; EW, HF performed the statistical analysis; EW, HF prepared the original draft; EW, HF revised the manuscript and performed editing. All authors read and approved the final manuscript.

\section{Acknowledgment}

The authors wish to thank St. Paul's Hospital Millennium Medical College staff and patients participated in this study

\section{References}

1. Mesquita EC, Coelho LE, Amancio RT, Veloso V, Grinsztejn B, Luz P, Bozza FA. Severe infection increases cardiovascular risk among HIV-infected individuals. BMC Infect Dis. 2019 Apr; 19:319

2. Isasti G, Pérez I, Moreno T, Cabrera F, Palacios R, Santos J. Echocardiographic Abnormalities and Associated Factors in a Cohort of Asymptomatic HIV-Infected Patients. AIDS Res Hum Retroviruses. 2013 Jan; 29(1):20-4

3. Hsue PY, Hunt PW, Ho JE, Farah HH, Schnell A, Hoh R, Martin JN, Deeks SG, Bolger AF. Impact of HIV Infection on Diastolic Function and Left Ventricular Mass. Circ Heart Fail. 2010 Jan; 3(1):132-9

4. Erqou S, Lodebo BT, Masri A, Altibi AM, Echouffo-Tcheugui JB, Dzudie A, Ataklte F, Choudhary G, Bloomfield Gs, Wu WC, Kengne AP. Cardiac dysfunction among people living with HIV: A systematic review and meta-analysis. JACC Heart Fail. 2019 Feb;7(2):98-108

5. Sud K, Argulian E. Echocardiography in Patients with HIV Infection. Curr Cardiol Rep. 2020 Aug; 22(9):100

6. Katz AS, Sadaniantz A. Echocardiography in HIV Cardiac Disease. Prog Cardiovasc Dis. 2003 JanFeb;45(4):285-92

7. Jain N, Reddy DH, Verma SP, Khanna R, Vaish AK, Usman K, Tripathi AK, Singh A, Mehrotra S, Gupta A. Cardiac Abnormalities in HIV-Positive Patients : Results from an Observational Study in India. J Int Assoc Provid AIDS Care. 2014 Jan-Feb; 13(1):40-6

8. Nzuobontane D, Blackett KN, Kuaban C. Cardiac involvement in HIV infected people in Yaounde, Cameroon. Postgrad Med J. 2002 Nov;78(925):678-81

9. Reinsch N, Kahlert P, Esser S, Sundermeyer A, Neuhaus K, Brockmeyer N, Potthoff A, Erbel R, Buck T, Neumann T. Echocardiographic findings and abnormalities in HIV-infected patients: results from a large, prospective, multicenter HIV-heart study. Am J Cardiovasc Dis. 2011 Aug;1(2):176-84. 
10. Rupal NP, Swati AC. Echocardiographic Profile of Human Immunodeficiency Virus (HIV) Infected Patients in a Tertiary Care Hospital. J Med Dent Sci. 2016 Jul;15(7):19-22

11. Unger T, Borghi C, Charchar F, Khan NA, Poulter NR, Prabhakaran D, Ramirez A, Schlaich M, Stergiou GS, Tomaszewski M, Wainford RD, Williams B, Schutte AE. 2020 International Society of Hypertension Global Hypertension Practice Guidelines. Hypertension. 2020 Jun;75(6):1334-1357

12. WHO. Physical Status: The Use and Interpretation of Anthropometry: Report of a World Health Organization (WHO) Expert Committee. Geneva, Switzerland: World Health Organization; 1995

13. Lang RM, Badano LP, Mor-Avi V, Afilalo J, Armstrong A, Ernande L, Flachskampf FA, Foster E, Goldstein SA, Kuznetsova T, Lancellotti P, Muraru D, Picard MH, Rietzschel ER, Rudski L, Spencer KT, Tsang W, Voigt JU. Recommendations for cardiac chamber quantification by echocardiography in adults: an update from the American Society of Echocardiography and the European Association of Cardiovascular Imaging. J Am Soc Echocardiogr. 2015 Jan;28(1):1-39.e14

14. Nagueh SF, Smiseth OA, Appleton CP, Byrd BF 3rd, Dokainish H, Edvardsen T, Flachskampf FA, Gillebert TC, Klein AL, Lancellotti P, Marino P, Oh JK, Popescu BA, Waggoner AD. Recommendations for the Evaluation of Left Ventricular Diastolic Function by Echocardiography: An Update from the American Society of Echocardiography and the European Association of Cardiovascular Imaging. J Am Soc Echocardiogr. 2016 Apr;29(4):277-314

15. Lang RM, Bierig M, Devereux RB, Flachskampf FA, Foster E, Pellikka PA, Picard MH, Roman MJ, Seward J, Shanewise J, Solomon S, Spencer KT, St John Sutton M, Stewart W; American Society of Echocardiography's Nomenclature and Standards Committee; Task Force on Chamber Quantification; American College of Cardiology Echocardiography Committee; American Heart Association; European Association of Echocardiography, European Society of Cardiology. Recommendations for chamber quantification. Eur J Echocardiogr. 2006 Mar;7(2):79-108

16. Huluka DK, Mekonnen D, Abebe S, Meshesha A, Mekonnen D, Deyessa N, Klinger JR, Ventetuolo CE, Schluger NW, Sherman CB, Amogne W. Prevalence and risk factors of pulmonary hypertension among adult patients with HIV infection in Ethiopia. Pulm Circ. 2020 Nov 25;10(4):2045894020971518

17. Klein AL, Abbara S, Agler DA, Appleton CP, Asher CR, Hoit B, Hung J, Garcia MJ, Kronzon I, Oh JK, Rodriguez ER, Schaff HV, Schoenhagen P, Tan CD, White RD. American Society of Echocardiography clinical recommendations for multimodality cardiovascular imaging of patients with pericardial disease: endorsed by the Society for Cardiovascular Magnetic Resonance and Society of Cardiovascular Computed Tomography. J Am Soc Echocardiogr. 2013 Sep;26(9):965-1012.e15

18. Longo-Mbenza B, Seghers LV, Vita EK, Tonduangu K, Bayekula M. Assessment of ventricular diastolic function in AIDS patients from Congo: a Doppler echocardiographic study. Heart. 1998 Aug;80(2):1849

19. Cardoso JS, Moura B, Martins L, Mota-Miranda A, Rocha Gonçalves F, Lecour H. Left ventricular dysfunction in human immunodeficiency virus (HIV)-infected patients. Int J Cardiol. 1998 Jan 5;63(1):37-4

20. Alvarado GR, Usry CR, Gore RS, Watts JA, Okulicz JF. Echocardiographic assessment of asymptomatic US Air Force members with early HIV infection. BMC Res Notes. 2019 Nov 29;12(1):783 
21. Kumar SR, Vishwanath C, Singh NN, Pal SA, Jyoti J, Harsh K, Singh SG, Khushpreet S. Study of Cardiac Manifestations in Patients with HIV Infection and Their Correlation with CD4 Count in Indian Population. Annals of International Medical and Dental Research. 2017 Jan-Feb; 3(1): 4-11

22. Jeong EM, Dudley SC Jr. Diastolic dysfunction. Circ J. 2015;79(3):470-7

23. Mondy KE, Gottdiener J, Overton ET, Henry K, Bush T, Conley L, Hammer J, Carpenter CC, Kojic E, Patel P, Brooks JT; SUN Study Investigators. High Prevalence of Echocardiographic Abnormalities among HIV-infected Persons in the Era of Highly Active Antiretroviral Therapy. Clin Infect Dis. 2011 Feb $1 ; 52(3): 378-86$

24. Mansoor A, Golub ET, Dehovitz J, Anastos K, Kaplan RC, Lazar JM. The association of HIV infection with left ventricular mass/hypertrophy. AIDS Res Hum Retroviruses. 2009 May;25(5):475-81

25. Pombo M, Olalla J, Del Arco A, De La Torre J, Urdiales D, Aguilar A, Prada JL, García-Alegría J, RuizMateas F. Left ventricular hypertrophy detected by echocardiography in HIV-infected patients. Eur J Intern Med. 2013 Sep;24(6):558-61

26. Drazner MH. The progression of hypertensive heart disease. Circulation. 2011 Jan 25;123(3):327-34

27. Mishra TK, Mishra SK, Singh S. Cardiovascular manifestations of people living with HIV/AIDS: Report from a hot spot in eastern India. Indian Heart J. 2019 Jul-Aug;71(4):338-343

28. Triant VA. Epidemiology of coronary heart disease in patients with human immunodeficiency virus. Rev Cardiovasc Med. 2014;15 Suppl 1(0 1):S1-8

29. So-Armah K, Benjamin LA, Bloomfield GS, Feinstein MJ, Hsue P, Njuguna B, Freiberg MS. HIV and cardiovascular disease. Lancet HIV. 2020 Apr;7(4):e279-e293

30. Ogunmodede JA, Kolo PM, Katibi IA, Salami AK, Omotoso A. Structural echocardiographic abnormalities seen in HIV/AIDS patients are independent of cd4 count. Niger J Clin Pract. 2017 Jun;20(6):716-723

31. Longo-Mbenza B, Seghers KV, Phuati M, Bikangi FN, Mubagwa K. Heart involvement and HIV infection in African patients: determinants of survival. Int J Cardiol. 1998 Mar 13;64(1):63-73

32. Menanga AP, Ngomseu CK, Jingi AM, Mfangam BM, Noubiap JJ, Gweth MN, Blackett KN, Kingue S. Patterns of cardiovascular disease in a group of HIV-infected adults in Yaoundé, Cameroon.

Cardiovasc Diagn Ther. 2015 Dec;5(6):420-7

33. Werneck GL, Mesquita ET, Romêo Filho LJ, Ribeiro ML. Doppler echocardiographic evaluation of HIVpositive patients in different stages of the disease. Arq Bras Cardiol. 1999 Aug;73(2):157-68

34. Himelman RB, Chung WS, Chernoff DN, Schiller NB, Hollander H. Cardiac manifestations of human immunodeficiency virus infection: a two-dimensional echocardiographic study. J Am Coll Cardiol. 1989 Apr;13(5):1030-6

35. Lind A, Reinsch N, Neuhaus K, Esser S, Brockmeyer NH, Potthoff A, Pankuweit S, Erbel R, Maisch B, Neumann T. Pericardial effusion of HIV-infected patients - Results of a prospective multicenter cohort study in the era of antiretroviral therapy. Eur J Med Res. 2011 Nov 10;16(11):480-3

36. Janda S, Shahidi N, Gin K, Swiston J. Diagnostic accuracy of echocardiography for pulmonary hypertension: a systematic review and meta-analysis. Heart. 2011 Apr;97(8):612-22 